STUDIA Z PRAWA WYZNANIOWEGO

Tom $24-2021$

DOI: https://doi.org/10.31743/spw.12686

JÓZEF KOREDCZUK

\title{
OD PRAWA KOŚCIELNEGO DO HISTORII PRAWA. POWIKŁANE POWOJENNE LOSY PROFESORA LESZKA WINOWSKIEGO
}

From Church law to history of law:

The complicated postwar life of Professor Leszek Winowski

Streszczenie: Artykuł ukazuje powojenne losy profesora Leszka Winowskiego, przedwojennego asystenta w Katedrze Prawa Kościelnego Uniwersytetu Jana Kazimierza we Lwowie, który po II wojnie światowej podjął zatrudnienie na Wydziale Prawa Uniwersytetu Wrocławskiego. Jego zatrudnienie, a także późniejsza praca na Wydziale Prawa we Wrocławiu wiązała się prawie przez cały okres z negatywnym nastawieniem do jego osoby władz komunistycznych, które z powodów ideologicznych niechętnie odnosiły się do przedwojennej kadry akademickiej. W przypadku L. Winowskiego główną przyczyną niechęci władz do jego osoby było zajmowanie się przez niego nieuznawaną przez władze komunistyczne dyscypliną naukową, jaką było prawo kościelne oraz jego dodatkowe zatrudnienie na Katolickim Uniwersytecie Lubelskim i różnorakie związki z Kościołem Katolickim. To spowodowało, że z konieczności został on zatrudniony w Katedrze Historii Prawa na Zachodzie Europy (później Zakładzie Powszechnej Historii Państwa i Prawa), starając się połączyć swoje dawne zainteresowania z zakresem tematycznym badań jednostki organizacyjnej, w której podjął zatrudnienie. Swoje zainteresowania naukowe oparte na wspomnianych uwarunkowaniach skupił na relacjach łączących Kościół na Śląsku z resztą Kościoła polskiego i polityce władz pruskich w stosunku do niego. Drugim nurtem badawczym, któremu poświęcił wiele prac, był stosunek Kościoła i głoszonej przez niego nauki do innowierców $\mathrm{w}$ okresie średniowiecza, a w związku z tym również prawo islamu, stając się

* Prof. dr hab., Instytut Historii Państwa i Prawa, Wydział Prawa, Administracji i Ekonomii, Uniwersytet Wrocławski, ul. Kuźnicza 46/47, 50-138 Wrocław, e-mail: jozef.koredczuk@uwr.edu.pl. ORCID 0000-0002-3471-586X. 
w tej kwestii niekwestionowanym autorytetem w Polsce. Powojenne wrocławskie losy profesora L. Winowskiego odzwierciedlają politykę państwa w stosunku do Kościoła w okresie PRL, stanowiąc również świadectwo realizowanej wówczas polityki naukowej.

Słowa kluczowe: Leszek Winowski; Katedra Prawa Kościelnego; prawo kościelne; prawo wyznaniowe; stosunki państwo-Kościół; Wydział Prawa Uniwersytetu Wrocławskiego

Abstract: The paper presents the postwar fate of Professor Leszek Winowski, a prewar research and teaching assistant at the Chair of Church Law at John Casimir University in Lviv, who after World War II took up employment with the Faculty of Law of the University of Wrocław. His His work for the Faculty in Wrocław was greatly affected by the negative attitude of the communist authorities already from the beginning. For ideological reasons, the authorities were ill-disposed toward the pre-war academic staff. In the case of L. Winowski, what also played a role was his field of research (Church law), which was not recognized by the communist authorities, his additional employment at the Catholic University of Lublin and his different affiliations with the Catholic Church. As a consequence, he had to be hired at the Chair of the History of Law in Western Europe (later the Department of General History of State and Law), trying to harmonize his former interests with the research done at the department in which he was employed. As a result, he focused his research interests on the relations between the Church in Silesia and the rest of the Polish Church, as well as on the Church policy of the Prussian authorities. Another research area in which he published broadly concerned the attitude of the Church and its teachings towards non-believers in the Middle Ages, and consequently also Islamic law, where he became an unquestionable authority in Poland. The postwar life of Professor L. Winowski in Wrocław reflects the State's policy towards the Church in the period of Polish People's Republic, also bearing testimony to the research policy pursued at the time.

Key words: Leszek Winowski; Chair of Church Law; Church law; law on religion; Church-State relations; Faculty of Law of the University of Wrocław

Profesora Leszka Winowskiego z księdzem profesorem Henrykiem Misztalem łączyło nie tylko wspólne miejsce pracy, jakim był Katolicki Uniwersytet Lubelski, ale przede wszystkim podobne zainteresowania naukowe. W dorobku naukowym obydwu profesorów niezwykle istotną część 
stanowiły bowiem zagadnienia dotyczące relacji łączących państwo z kościołami i związkami wyznaniowymi i vice versa.

Leszek Winowski urodził się 23 stycznia 1910 r. w Skałacie (powiat tarnopolski). Pochodził z rodziny sędziowskiej, dlatego też nie dziwi, że wybrał studia na Wydziale Prawa Uniwersytetu Jana Kazimierza. Po ich ukończeniu w 1932 r. został uczniem Władysława Abrahama i Leona Halbana. Pierwszy z nich - W. Abraham był kierownikiem Katedry Prawa Kościelnego w latach 1888-1936, drugi zaś - L. Halban w latach 1936-1939. Prowadzone w tym czasie na Uniwersytecie Jana Kazimierza przez W. Abrahama seminarium było wówczas najlepszą szkołą historii prawa kościelnego w Polsce ${ }^{1}$. W. Abraham i L. Halban wywarli istotny wpływ na zainteresowania naukowe L. Winowskiego na całe życie, którymi stały się prawo kościelne (dzisiaj określane wyznaniowym) i dzieje stosunków państwo-Kościół na przestrzeni dziejów. Dnia 1 listopada 1933 r. został on zatrudniony jako asystent wolontariusz w Katedrze Prawa Kościelnego, kierowanej przez W. Abrahama. Pierwszym potwierdzeniem jego zainteresowań prawem kościelnym był doktorat Przywileje kleru w konkordatach XIX $i$ XX w., obroniony 6 lipca 1935 r. Recenzentami jego rozprawy byli W. Abraham i Ludwik Ehrlich, kierownik Katedry Prawa Narodów i Ogólnej Nauki o Państwie. Utrzymując kontakty naukowe z Karolem Koranyim interesował się również historią ustrojów państwowych na zachodzie Europy². Dalszą jego pracę na Uniwersytecie we Lwowie przerwał wybuch II wojny światowej.

Po zakończeniu II wojny światowej, po krótkich pobytach w Rzeszowie, Sopocie i w Olsztynie, w grudniu 1945 r. L. Winowski przyjechał do Wrocławia, gdzie po wojnie osiadło najwięcej byłych pracowników Wydziału Prawa Uniwersytetu Jana Kazimierza. Było to niewątpliwie zasługą Kamila Stefki, organizatora i pierwszego dziekana Wydziału Prawno-Administracyjnego Uniwersytetu Wrocławskiego. Był on osobą do tego zadania jak najbardziej odpowiednią, sprawował bowiem funkcję dziekana lub prodziekana Wydziału Prawa Uniwersytetu Lwowskiego w trudnych dla niego czasach, m.in. pod koniec I wojny światowej i po odzyskaniu przez Polskę niepodległości w latach 1917-1920 czy po przewrocie

Pisulińska 2012, 230.

2 Klein, Koredczuk 2020, 417; Kaczorowski 2020, 179. 
majowym w latach 1926-1932³. Szczególnie doświadczenia z tego pierwszego okresu mogły być przydatne dla K. Stefki podczas organizacji Wydziału Prawa we Wrocławiu po zakończeniu kolejnej wojny, którą dane było mu przeżyć.

Formalną podstawą organizacji Uniwersytetu Wrocławskiego i w ramach niego Wydziału Prawa były jeszcze przedwojenne przepisy ustawy z dnia 15 marca 1933 r. o szkolnictwie wyższym ${ }^{4}$. Biorąc pod uwagę przedwojenną strukturę wydziałów prawa, K. Stefko podjął starania o skompletowanie kadry naukowej, która objęłaby poszczególne jednostki organizacyjne na tworzonym Wydziale i podjęła nauczanie studentów. Swoje kroki w pierwszej kolejności skierował on do swoich kolegów z Wydziału Prawa Uniwersytetu Jana Kazimierza, których najwięcej - w sumie 16 osób przybyło do Wrocławia (zwanego „nowym Lwowem”) ${ }^{5}$. Jedną nich przewidzianą do zatrudnienia w przyszłej Katedrze Prawa Kościelnego był L. Winowski. Miał zostać zatrudniony na stanowisku młodszego pracownika naukowego - zastępcy profesora, ponieważ na stanowisko kierownika Katedry planowano powołać L. Halbana. Z wnioskiem o jego nominację na stanowisko profesora wystąpił do Ministerstwa rektor Uniwersytetu Wrocławskiego, Stanisław Kulczyński, już 8 października 1945 r. W rzeczywistości L. Halban nigdy do Wrocławia nie dojechał, początkowo z powodu choroby, a później z tego powodu, że podjął pracę na Katolickim Uniwersytecie Lubelskim 6 .

Wśród utworzonych na podstawie zarządzenia Ministra Oświaty z dnia 30 kwietnia 1946 r. na Wydziale 17 katedr nie było Katedry Prawa Kościelnego-mimo że, z małymi wyjątkami, odpowiadały one katedrom przedwojennym $^{7}$. Decyzją z dnia 22 maja 1946 r. Ministerstwo odrzuciło wniosek Rady Wydziału o utworzenie Katedry Prawa Kościelnego. Stało się tak z motywów ideologicznych, nie tylko zresztą na Wydziale Prawa we Wrocławiu ${ }^{8}$ Z ponownym wnioskiem do Ministerstwa o reaktywowanie

\footnotetext{
3 Redzik 2010, 118-119.

4 Ustawa z dnia 15 marca 1933 r. o szkolnictwie wyższym, Dz. U. z 1933 r. Nr 29, poz. 247.

5 Koredczuk 2020, 9.

6 Koredczuk 2007a, 10-11.

7 Pyter 2008, 19-28.

8 Jonca 1996, 24-25; Koredczuk 2020, 11.
} 
prawa kościelnego Rada Wydziału wystąpiła na posiedzeniu 24 września 1946 r. Argumentem, na który powołała się Rada, stanowił fakt, że prawo kościelne było przedmiotem obowiązkowym w programie nauczania. Próbą wyjścia z zaistniałej sytuacji był zgłoszony przez zastępcę profesora Józefa Fiemę (znanego aktywistę partyjnego) na Radzie Wydziału 4 lutego 1947 r. wniosek, by zwrócić się do Ministerstwa Oświaty o przemianowanie (nieistniejącej formalnie) Katedry Prawa Kościelnego w Katedrę Państwowego Prawa Wyznaniowego. Również i te wnioski z powodów politycznych nie doczekały się rozpatrzenia przez Ministerstwo9. Od 1947 r. można było bowiem zauważyć narastanie presji ideologicznej na życie naukowe w Polsce, zmierzającej do zdominowania podstawowych założeń metodologicznych prowadzonych badań wpływami marksizmu oraz dążenie do podporządkowania struktur organizacyjnych wzorcom zaczerpniętym wprost z przykładów radzieckich ${ }^{10}$.

Mimo nieutworzenia Katedry Prawa Kościelnego, zajęcia dydaktyczne z prawa kościelnego były przewidziane już w programie roku akademickiego 1945/1946. Wykłady z tego przedmiotu (nazywanego także prawem wyznaniowym porównawczym) w wymiarze godzin z 1939 r. na II roku studiów - w zastępstwie L. Halbana, który miał je objąć w kwietniu 1946 r. - prowadził L. Winowski. Natomiast ćwiczenia - Michał Kostecki, adiunkt w Katedrze Prawa Administracyjnego (przedwojenny asystent na Wydziale Prawa UJK, podobnie jak L. Winowski zatrudniony w Katedrze Prawa Kościelnego). Wykłady z prawa kościelnego odbywały się w poniedziałki i soboty w godz. 11-13, a ćwiczenia zaraz po wykładzie (ewentualnie od godz. 16). W roku akademickim 1946/1947 L. Winowski wykładał także przedmiot „Stosunek Kościoła do Państwa”, na który miał po jednej godzinie wykładu w każdym trymestrze ${ }^{11}$.

$\mathrm{Na}$ marginesie warto dodać, że obrona doktoratu M. Kosteckiego, pt. Stosunek kościoła do państwa na tle ostatnich encyklik i konkordatów, która miała miejsce 9 czerwca 1946 r. była pierwszą obroną na polskim Wydziale Prawa we Wrocławiu. Było to możliwe dzięki temu, że już przed

\footnotetext{
9 Mycielski 2012, 400; Koredczuk 2007a, 51.

10 Wrzesiński 1994, 105.

11 Koredczuk 2007a, 47.
} 
wojną we Lwowie pracę tę przyjęli do obrony profesorowie Przemysław Dąbkowski, L. Ehrlich i L. Halban ${ }^{12}$.

Po odmowie utworzenia Katedry Prawa Kościelnego przez Ministerstwo, zajęcia z prawa kościelnego zostały przemianowane na zajęcia z prawa wyznaniowego. Ćwiczenia z nich prowadził M. Kostecki (który w lutym 1948 r. niespodziewanie zmarł), zaś wykłady L. Winowski. Jego wykłady na I Ogólnopolskiej Konferencji Historyków Prawa w Toruniu w 1950 r. skrytykował sam ówczesny minister sprawiedliwości Henryk Świątkowski (luminarz socjalistycznej nauki prawa wyznaniowego), mówiąc, że nie są to wykłady z prawa wyznaniowego, lecz kanonicznego ${ }^{13}$.

Natomiast gdy idzie o egzaminy z prawa wyznaniowego w 1946 r., to, oprócz L. Winowskiego, przeprowadzał je także Iwo Jaworski. Egzamin $\mathrm{z}$ prawa wyznaniowego $\mathrm{w}$ tamtych czasach budził podobny respekt, jak z prawa rzymskiego, uchodząc za jeden $\mathrm{z}$ trudniejszych ${ }^{14}$. Na potrzeby zajęć z prawa wyznaniowego L. Winowski przygotował skrypt Państwowe prawo wyznaniowe (Wrocław 1948), zaś do programu studiów na Wydziale w 1946 r., jako przedmiot do wyboru o charakterze monograficznym, zaproponował wykład zatytułowany „Administracja wyznaniowa"15.

Mając kłopoty z zatrudnieniem, L. Winowski przewidywał, że również może mieć problem z przeprowadzeniem na Wydziale Prawno-Administracyjnym we Wrocławiu swojej habilitacji pt. Stosunek chrześcijaństwa pierwszych wieków do wojny, dlatego też zrobił to w sierpniu 1946 r. na Wydziale Prawa i Nauk Społeczno-Ekonomicznych KUL. Rozprawę tę zaprezentował już na wiosnę 1939 r. na posiedzeniu Sekcji Prawno-Historycznej Lwowskiego Towarzystwa Naukowego. Wybuch wojny uniemożliwił niestety dalsze procedowanie nad nią ${ }^{16}$. Nie omylił się w tym względzie. Potwierdzeniem tego, że L. Winowski miałby kłopoty z przeprowadzeniem habilitacji we Wrocławiu są losy habilitacji równie nieprawomyślnego jak L. Winowski - Franciszka Longchamps de Bériera - którego

12 Mycielski 2012, 398.

13 Koredczuk 2007a, 51.

14 Tamże, 22.

15 Tamże, 52.

16 Pogląd na stosunek chrześcijaństwa pierwszych wieków do wojny, ,Sprawozdania Towarzystwa Naukowego we Lwowie" 1937, nr 17, z. 3, s. 230-233; Kaczorowski 2020, $179,182$. 
habilitacja pt.Założenia naukiadministracji przeprowadzonaw 1949r.mimo przyjęcia jej przez Radę Wydziału we Wrocławiu nie została jednak zatwierdzona w 1951 r. przez Ministerstwo Szkół Wyższych i Nauki. Swoją decyzję Ministerstwo uzasadniło tym, że jest ona niezgodna ,z duchem ustroju państwa", dlatego też ponadto nakazało przeznaczyć jej egzemplarze na makulaturę. Jedynie dzięki temu, że udało się zachować jej nieliczne egzemplarze, było możliwe jej powtórne opublikowanie, po zmianach politycznych w Polsce, w 1991 r. ${ }^{17}$

Nie mogąc zostać zatrudnionym w Katedrze Prawa Kościelnego, a gdzieś przecież musiał pracować, L. Winowski został początkowo zatrudniony jako adiunkt w Katedrze Prawa Narodów (będąc jednym z pierwszych mianowanych adiunktów na Wydziale). Po tym jednak, gdy Ministerstwo Oświaty odmówiło jego dalszego zatrudnienia także i w tej Katedrze, Rada Wydziału postanowiła przesunąc go na etat w Katedrze Historii Prawa na Zachodzie Europy, w której podjął pracę od 1 października 1948 r. ${ }^{18}$ Stało się to możliwe, gdyż w Katedrze tej nie było nikogo z młodszej kadry, kto mógłby prowadzić ćwiczenia. Zaadaptowanie się L. Winowskiego w tej Katedrze było o tyle prostsze, że już we Lwowie utrzymywał on kontakty naukowe z K. Koranyim (późniejszym czołowym przedstawicielem powszechnej historii państwa i prawa w Polsce).

Wątpliwości natury politycznej, co do osoby L. Winowskiego, były non stop zgłaszane. Wysuwał je m.in. na początku 1956 r. Komitet Uczelniany PZPR, który określił go jako zdecydowanego idealistę, i który pomimo interwencji uniwersyteckiej organizacji partyjnej w Ministerstwie pracował dalej bez przeszkód na Wydziale. Kryje się tu pewien paradoks. Komitet Uczelniany interweniował bowiem w Ministerstwie, chyba po to, by wykazać się aktywnością. Natomiast to, że L. Winowski dalej pracował na Wydziale było możliwe dzięki interwencji jego I sekretarza, Józefa Orzeszyny, starszego asystenta w Katedrze Teorii Państwa i Prawa (natomiast w latach 60. kierownika Urzędu Spraw Wewnętrznych we Wrocławiu) $^{19}$.

\footnotetext{
17 Kmieciak 2019, 6-7.

18 Koredczuk 2007a, 10; Koredczuk 2015, 52-53.

19 Koredczuk 2007b, 92; Koredczuk 2020, 249.
} 
Drugą osobą zatrudnioną na Wydziale, która także budziła niepokój uczelnianych władz partyjnych w tym czasie, był ksiądz profesor Michał Wyszyński (także uczeń W. Abrahama) ${ }^{20}$. Przybył on do Wrocławia z Torunia (pod koniec 1953 r. po rozwiązaniu tam Wydziału Prawa), z inicjatywy kierującego Katedrą Prawa Rzymskiego działacza partyjnego Jerzego Falenciaka i przejął wykłady z prawa rzymskiego po Wacławie Osuchowskim² ${ }^{21}$.

Podlegając ciągłej presji ze strony władz politycznych (partyjnych) L. Winowski w 1957 r. ostatecznie zrezygnował z pracy na KUL. Nie zerwał jednak więzi naukowych łączących go z KUL, zostając chociażby w 1958 r. członkiem Towarzystwa Naukowego KUL oraz uczestnicząc w licznych przewodach doktorskich przeprowadzonych na tej Uczelni. Więzi te utrzymywał do końca swego życia ${ }^{22}$. Po rezygnacji z pracy na KUL zaproponowano mu zatrudnienie w Wyższej Szkole Pedagogicznej w Opolu. Pracował w niej kolejne 11 lat, od 1957 r. do 1968 r.

Zapewne nie przestając być obiektem zainteresowania służb specjalnych, w warunkach „odwilży” po październiku 1956 r., po kilkumiesięcznym postępowaniu w 1957 r. został profesorem nadzwyczajnym oraz prodziekanem Wydziału Prawa od 17 lutego 1957 r. do 30 września 1958 r. Stan ten ,przychylnego wobec niego nastawienia służb specjalnych" nie trwał jednak długo. Wierzący w zmiany w Polsce po październiku 1956 r., L. Winowski zaangażował się w działalność Klubu Inteligencji Katolickiej we Wrocławiu. Według informatorów SB w 1960 r. był on jednym $\mathrm{z}$ czołowych aktywistów tego $\mathrm{Klubu}^{23}$. Również wszczęte w 1966 r. postępowanie o nadanie mu tytułu profesora zwyczajnego, z różnych przyczyn pozanaukowych trwało aż do listopada $1974 \mathrm{r}^{24}$

Mimo powyższych przeciwności, L. Winowski przez cały okres pracy na Wydziale Prawa Uniwersytetu Wrocławskiego prowadził swoją prywatną wojnę z „,czerwoną religią”, jak to określił Aleksander Małachowski $^{25}$, która dotarła na Wydział w latach 40. Pozostając wierny swoim ideałom naukowym wpojonym mu we Lwowie, m.in. po wydarzeniach

\footnotetext{
20 Wrzesiński 1995, 174-175; Koredczuk 2020, 249.

21 Ryszka 1996, 49.

22 Kaczorowski 2020, 182.

23 Szymanowski 2009, 88.

24 Kaczorowski 2020, 183.

25 Mackiewicz 2012, 87.
} 
marcowych w 1968 r. zrezygnował z zasiadania w Senackiej Komisji Dyscyplinarnej do Spraw Studentów, a następnie z pracy w Wyższej Szkole Pedagogicznej w Opolu ${ }^{26}$.

Zatrudnienie od 1948 r. w Katedrze Historii Prawa na Zachodzie Europy, przemianowanej na mocy $\S 1$ pkt C ppkt 2) i 3) rozporządzenia Ministra Szkół Wyższych i Nauki z dnia 21 sierpnia 1950 r. ${ }^{27}$ w Katedrę Powszechnej Historii Państwa i Prawa, której kierownictwo po śmierci I. Jaworskiego objął 1 lipca 1959 r. spowodowało, że także pod względem naukowym musiał się dostosować do jej profilu naukowego. Z czasem, w miarę upływu jego zatrudnienia w Katedrze (od 1969 r. Zakładzie) Powszechnej Historii Państwa i Prawa, jego zainteresowania naukowe koncentrowały się głównie na trzech problemach badawczych: 1) historii związków organizacyjno-kościelnych łączących Śląsk z Rzecząpospolitą, 2) stosunku europejskich państw chrześcijańskich do innowierczego otoczenia, 3) państwie i prawie islamu ${ }^{28}$.

Pierwszy z nurtów badawczych w twórczości L. Winowskiego, czyli historia związków organizacyjno-kościelnych łączących Śląsk z Rzecząpospolitą, miał w latach 50. niezwykle istotne znaczenie polityczne. Podstawowym bowiem zadaniem badaczy polskich było udzielenie odporu na poglądy głoszone w tym względzie w ówczesnej nauce kapitalistycznej. Odnosiło się to także do dziejów Kościoła na Śląsku i jego relacji z resztą Kościoła polskiego zwłaszcza w okresie do 1795 r. W tym nurcie badawczym należy wskazać na dwa artykuły L. Winowskiego: Stosunki między biskupstwem wrocławskim a metropolia gnieźnieńska $w$ latach 1740-1748 („Przegląd Zachodni” 1955, t. 11, nr 3-4, s. 613-692) i Polityka kościelna Fryderyka II na Ślasku (Uwagi na tle pracy F. Hanusa, Church and State in Silesia under Frederick II, Washington 1944) („Studia Śląskie. Seria Nowa” 1958, t. I, s. 233-252). Pierwszy z tych artykułów Wincenty Urban uznał za bardzo wnikliwą pracę, dotyczącą tego

26 Kaczorowski 2020, 185.

27 Rozporządzenie Ministra Szkół Wyższych i Nauki z dnia 21 sierpnia 1950 r. w sprawie zmian organizacyjnych w niektórych szkołach akademickich, Dz. U. z 1950 r. Nr 41, poz. 368 .

28 Koredczuk 2015, 57. 
problemu badawczego ${ }^{29}$. Drugi artykuł był natomiast polemiką z ustaleniami badaczy niemieckich.

Prace L. Winowskiego, dotyczące stosunku europejskich państw chrześcijańskich do innowierczego otoczenia, można określić jako kontynuację nurtu badawczego zainicjowanego w jego rozprawie habilitacyjnej. Należą do nich: Stosunek średniowiecznej Europy do obcych-innowierców (Zarys problemu) („Prawo Kanoniczne” 1961, t. 4, nr 1-4, s. 593-680); Sprawa stosunku do pogan w polsko-krzyżackim procesie z lat 1412-1414 (,Zeszyty Naukowe Uniwersytetu Wrocławskiego. Seria A. Prawo” 1956, t. II, nr 6, s. 99-117); Innowiercy w średniowiecznych wyobrażeniach i legendach („Studia Śląskie. Seria Nowa” 1971, t. XX, s. 523-540); Innowiercy zewnętrzni $w$ przepisach Corpus Iuris Canonici („Acta Universitatis Wratislaviensis. Przegląd Prawa i Administracji” 1972, t. I, nr 144, s. 187-197); Innowiercy wewnętrzni w przepisach Corpus Iuris Canonici („Acta Universitatis Wratislaviensis. Przegląd Prawa i Administracji” 1972, t. II, nr 167, s. 237-252); Decyzje papieskie $w$ sprawach innowierców (od połowy XI do końca XIII w.) („Acta Universitatis Wratislaviensis. Przegląd Prawa i Administracji” 1973, t. III, nr 168, s. 219-236); Prawo i myśl chrześcijańska XIII w. wobec sprawy innowierców. Założenia wstępne (w: Z zagadnień kultury chrześcijańskiej, kom. red. K. Wojtyła et al., Lublin 1973, s. 341-351); Mahomet w oczach Piusa II („Prawo Kanoniczne" 1978, t. 21, nr 1-2, s. 15-28). Dotyczą one, co warto podkreślić, jakże ważnego i trudnego, zarówno dawniej, jak i dziś styku pomiędzy światem chrześcijańskim a muzułmańskim.

Trzeci z nurtów zainteresowań naukowych L. Winowskiego stanowiły badania nad państwem i prawem islamu. Jest on w tym zakresie Autorem następujących publikacji: Koran, jego powstanie $i$ znaczenie jako źródło prawa islamu („Roczniki Teologiczno-Kanoniczne” 1963, t. 10, z. 4, s. 197-213); Z zagadnień prawa i państwa Islamu („Acta Universitatis Wratislaviensis. Prawo" 1964, t. XII, nr 19, s. 251-270); Państwo Islamu w czasach Mahometa i kalifów prawowiernych (610-661) (Opole 1966); Organizacja i prawo kalifatu Omajjadów („Acta Universitatis Wratislaviensis. Prawo" 1967, t. XVIII, nr 63, s. 27-51); Ksztalt prawny

29 Urban 1968, 320. 
współczesnego państwa islamu (,Acta Universitatis Wratislaviensis. Prawo" 1971, t. XXXIV, nr 138, s. 61-75).

Natomiast prace L. Winowskiego nad historią państwa i prawa islamu w latach 50. i 60. miały unikatowy charakter. O jego poważnym podejściu do nich świadczyć może fakt, iż pragnąc pogłębić swoje studia nad prawem islamu, planował pod koniec 1959 r. wyjazd do Iraku, co spotkało się z pozytywną opinią władz Wydziału ${ }^{30}$. Pragnąc swoimi badaniami zainteresować studentów do programu studiów na Wydziale zaproponował m.in. wykłady do wyboru „Historia prawa i ustroju islamu” oraz „Podstawy prawa i ustroju islamu". Natomiast w roku akademickim 1962/1963 i 1963/1964 dla IV roku studiów (dla seminariów z: powszechnej historii państwa i prawa, historii doktryn politycznych i prawnych, prawa rzymskiego oraz prawa narodów publicznego i prywatnego) prowadził wykład z „Prawa islamu” 31 . Bliskość problematyki państwa i prawa islamu dla L. Winowskiego brała się stąd, że islam jako kultura prawna wyróżnia się wśród innych kultur prawnych przede wszystkim tym, iż obok nakazów ściśle religijnych zawiera normy moralne i normy prawne, stanowiące podstawę organizacji wszystkich stron życia dla muzułmanów ${ }^{32}$. Odgrywa on zatem podobną rolę jak religia i prawo kościelne (kanoniczne) dla chrześcijan. Nieprzypadkowo prawo jest ważnym aspektem kultury dla muzułmanów. „Szari’at”, czyli prawo, oznacza bowiem „drogę”33.

Być może planowanym przez L. Winowskiego opus vitae miała być rozprawa pt. Innowiercy $w$ pogladach uczonych zachodniego chrześcijaństwa XIII-XIV wieku. Prace nad nią rozpoczął w 1975 r. w ramach planu badań naukowych prowadzonych w Instytucie Historii Państwa i Prawa Uniwersytetu Wrocławskiego, w związku z pięcioletnim rządowym planem rozwoju nauki i techniki na lata 1976-1980. Zakończenie podjętych badań L. Winowski planował w roku $1980^{34}$. Jego śmierć przerwała te prace. Trud jego nie poszedł jednak na marne. Na podstawie jego maszynopisu, po

30 Koredczuk 2007b, 92

31 Koredczuk 2007a, 52-54.

32 Tokarczyk 2000, 219.

33 Sadowa, Kuriata 2015, 211.

34 Plany z 1976 r. Plany i sprawozdania Instytutu Historii Państwa i Prawa Uniwersytetu Wrocławskiego za lata 1973/74 do 1975/76. Wrocław: Instytut Historii Państwa i Prawa, s. $207,212$. 
uzupełnieniu przez Kazimierza Orzechowskiego, rozprawa ta ukazała się drukiem w 1985 r.

Powojenne wrocławskie losy profesora L. Winowskiego są jednym z epizodów składających się na politykę wyznaniową państwa w stosunku do osób związanych z Kościołem w okresie PRL, a także interesującym przyczynkiem ukazującym politykę naukową państwa w tym okresie. Dzięki L. Winowskiemu wrocławski ośrodek powszechnej historii państwa i prawa stał się jednym z wyróżniających się ośrodków w Polsce do końca lat 70. w badaniach nad dziejami Kościoła, prawa kanonicznego oraz stosunków kościelno-państwowych ${ }^{35}$.

L. Winowski po długiej chorobie zmarł we Wrocławiu na udar serca dnia 16 listopada 1979 r. Żegnający go K. Orzechowski, stojąc nad jego grobem przywołał wielokrotnie powtarzane przez L. Winowskiego słowa: „W każdym człowieku i w każdym studencie zobacz to, co jest w nim dobrego”. Nawiązując do nich można powiedzieć, że „w Leszku Winowskim można było zobaczyć tylko samo dobro".

\section{BIBLIOGRAFIA}

Jonca, Karol. 1996. Wydziat Prawa i Administracji Uniwersytetu Wrocławskiego 1945-1995. Wrocław: Wydawnictwo Uniwersytetu Wrocławskiego.

Kaczorowski, Włodzimierz. 2020. „Profesor Leszek Winowski (1910-1979), kanonista, historyk państwa i prawa. W 110. rocznicę urodzin i 40. rocznicę śmierci”. Opolskie Studia Administracyjno-Prawne 18/1: 175-187.

Klein, Edmund, Józef Koredczuk. 2020. „Leszek Winowski (1910-1979)”. W: Pamięci zmarlych Profesorów i Docentów Wydziału Prawa, Administracji i Ekonomii Uniwersytetu Wrocławskiego 1945-2020, red. Lucyna Lehmann, Marek Maciejewski, 417-420. Wrocław: Uniwersytet Wrocławski.

Kmieciak, Zbigniew. 2019. „Wstęp”. W: Franciszek Longchamps de Bérier. Pisma wybrane z lat 1934-1970, red. Zbigniew Kmieciak, 5-13. Warszawa: Wolters Kluwer.

Koredczuk, Józef. 2007a. „60-lecie powołania katedr historyczno-prawnych na Wydziale Prawa Uniwersytetu Wrocławskiego". Acta Universitatis Wratislaviensis. Prawo. Studia Historycznoprawne 303: 9-73.

35 Tyrchan 2012, 210. 
Koredczuk, Józef. 2007b. „Wspomnienia i plotki, czyli o tych, co odeszli, lecz w pamięci pozostali". Acta Universitatis Wratislaviensis. Prawo. Studia Historycznoprawne 303: 75-101.

Koredczuk, Józef. 2015. „Dzieje Zakładu Powszechnej Historii Państwa i Prawa Uniwersytetu Wrocławskiego". Acta Universitatis Wratislaviensis. Przeglad Prawa i Administracji 100/1: 49-68.

Koredczuk, Józef. 2020. „«Niepasujący władzy» na Wydziale Prawa Uniwersytetu Wrocławskiego w latach 1945-1956". W: Prawo i czas. Księga jubileuszowa z okazji 80-lecia urodzin Profesora Adama Lityńskiego, red. Maciej Borski, Dorota Fleszer, Andrzej Pokora, Anna Rogacka-Łukasik, 245-259. Sosnowiec: Oficyna Wydawnicza „Humanitas”.

Mackiewicz, Marta. 2012. „Istota państwa według Aleksandra Małachowskiego”. W: Prawnicy na Uniwersytecie Wrocławskim, red. Maciej Marszał, Jacek Przygodzki, 85-95. Wrocław: Wydawnictwo Uniwersytetu Wrocławskiego.

Mycielski, Andrzej. 2012. Chwile czasu minionego. Warszawa: Wydawnictwo Szkoły Wyższej Przymierza Rodzin.

Pisulińska, Joanna. 2012. Lwowskie środowisko historyczne w okresie międzywojennym (1918-1939). Rzeszów: Wydawnictwo Uniwersytetu Rzeszowskiego. Pyter, Magdalena. 2008. „Zasady funkcjonowania wydziałów prawa na uniwersytetach w latach 1918-1939". Przeglad Prawno-Ekonomiczny 3: 19-28.

Redzik, Adam. 2010. „Wydział Prawa Uniwersytetu Lwowskiego w okresie Drugiej Rzeczypospolitej i w czasie II wojny światowej”. Prace Komisji Historii Nauki Polskiej Akademii Umiejętności 10: 111-152.

Ryszka, Franciszek. 1996. Pamiętnik inteligenta. Samo życie. Łódź: Dom Wydawniczy ARS.

Sadowa, Katarzyna, Agnieszka Kuriata. 2015. „Rozwój kultury prawnej islamu wprowadzenie do tematyki”. W: Z badań nad prawem, administracja i myśla polityczna, red. Mirosław Sadowski, 207-222. Wrocław: Wydział Prawa, Administracji i Ekonomii Uniwersytetu Wrocławskiego.

Szymanowski, Adam. 2009. „Polityka władz komunistycznych wobec Kościoła rzymskokatolickiego na Dolnym Śląsku w latach 1960-1966". Papieski Wydział Teologiczny we Wrocławiu, praca doktorska, https://www.dbc.wroc. $\mathrm{pl} /$ publication $/ 4924$

Tokarczyk, Roman. 2000. Współczesne kultury prawne. Kraków: Zakamycze. Tyrchan, Mikołaj. 2012. „Nauki historycznoprawne w latach 70. XX w. - rozwój badań i międzynarodowych kontaktów, główne publikacje naukowe". Studia z Dziejów Państwa i Prawa 12: 179-222.

Urban, Wincenty. 1968. „Jeszcze o egzempcji diecezji wrocławskiej”. Prawo Kanoniczne 11/1-2: 319-325. 
Wrzesiński, Wojciech. 1994. „Rola Uniwersytetu Wrocławskiego w kształtowaniu śląskiego środowiska naukowego po II wojnie światowej”. W: Studia i materiały z dziejów Uniwersytetu Wrocławskiego, T. III, red. Teresa Kulak, Wojciech Wrzesiński, 99-116. Wrocław: Wydawnictwo Uniwersytetu Wrocławskiego. Wrzesiński, Wojciech. 1995. Uniwersytet Wrocławski 1945-1995. Wrocław: Wydawnictwo Leopoldinum Fundacji dla Uniwersytetu Wrocławskiego. 